\title{
Aspects of Fiscal Devolution in South Africa
}

\section{Grote}

Tax Policy Chief Directorate: The Budget Office, Department of Finance, Pretoria

N J Schoeman, M L Truu, J H van Heerden and $\mathbf{J} \mathbf{J}$ van Tonder Department of Economics, University of Pretoria

\section{ABSTRACT}

This paper is the joint product of a think tank, initiated in the public sector and extended to a group of academics. It may be seen as the executive summary of a rather voluminous report for internal use in the Department of Finance on fiscal federalism, one of the large economic issues facing the New South Africa. Debate on the subject continues.

JEL H 70

\section{INTRODUCTION}

South Africa operates as a unitary - in contrast with a federal - state, however, with certain federal characteristics. Alternatively put, South Africa has a cooperative form of governance, brought about by its particular circumstances and development. Like many other countries, government in South Africa typically functions at three tiers (or levels) of authority; central (or national), provincial and local (or municipal). This paper is explicitly addressed to the fiscal relationship between the central and provincial authorities; in particular, the division of the power to tax between them.

The direct reason for investigating this relationship derives from section $228(1)$ of the South African Constitution of 1996, to the following effect:

A provincial legislature may impose -

(a) taxes, levies and duties other than income tax, value-added tax, general sales tax, rates on property or customs duties; and

(b) flat-rate surcharges on the tax bases of any tax, levy or duty that is imposed by national legislation, other than the tax bases of corporate income tax, value-added tax, rates on property or customs duties. 
Whereas section $288(1)$ above refers to potentially new sources of provincial revenue, section $288(2)$ below states the constraints to which the concomitant power to tax is subject, namely, the following:

The power of a provincial legislature to impose taxes, levies, duties and surcharges -

(a) may not be exercised in a way that materially and unreasonably prejudices economic policies, economic activities across provincial boundaries, or the national mobility of goods, services, capital or labour; and

(b) must be regulated in terms of an Act of Parliament, which may be enacted only after any recommendations of the Financial and Fiscal Commission have been considered.

It would appear that a (provincial) surcharge on the (national) personal income tax base is potentially the most important source of provincial revenue. The surcharge has however become a contested issue in authoritative circles, and it also represents a pivotal concept in this paper. Two different approaches to the matter are taken by the Financial and Fiscal Commission (FFC) on the one hand, and in the seventh interim report of the Commission of Inquiry into Certain Aspects of the Tax Structure of South Africa (Katz Commission) on the other.

The FFC makes the assumption that "the [provinces'] capacity to raise more own source revenues, is justified on the grounds of promoting democratic and fiscally accountable government in the provinces". It then proceeds to conclude and recommend that the provincial authorities should be empowered to impose a flat-rate (proportional) surcharge on the national base of personal income tax (PIT). In contrast, the Katz Commission's "preferred choice ... at this point in time would be not to adopt the PIT surcharge option" (1998: 6). Of all the alternatives considered, the Katz Commission "is of the opinion that the most favourable would be the assignment of [a] fuel levy to the provinces in the medium term (1998: 8)". This option has again been dismissed by the FFC $(\mathrm{KC}, 1998: 7)$.

\section{THEORETICAL BACKGROUND}

The scientific literature on Public Finance (or Public Economics) is vast. Yet, there is no unique theory or model that may be deemed to have captured the best possible (or optimal) distribution of fiscal targets (functions) and instruments (mainly taxes) between different tiers of government. In general, 
the value of every individual target is determined by the values of all the available instruments:

$$
\begin{aligned}
& \mathrm{x}_{1}=\mathrm{x}_{1}\left(\mathrm{t}_{1} \ldots \ldots \ldots \ldots \ldots \mathrm{t}_{\mathrm{M}}\right)
\end{aligned}
$$

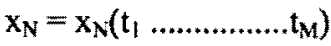

where $x_{i}$ refers to target $i ; i=1, \ldots N$, and $t_{j}$ refers to instrument $j ; j=1, \ldots, M$.

Likewise, the value of any one instrument is generally determined by all the existing targets:

$$
\begin{aligned}
& t_{1}=t_{1}\left(x_{1} \ldots \ldots \ldots \ldots x_{N}\right)
\end{aligned}
$$

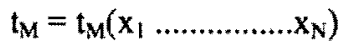

This matrix of interdependence makes it particularly difficult to predict the economic consequences when targets and/or instruments are redistributed between different tiers of government.

The degree of affinity between individual targets and instruments is, however, variable in practice. For example, a specific instrument, $t_{k}$, may be closely related to a particular target, say $x_{b}$, which at the same time depends on other instruments only to a limited degree. In this case the value of $\frac{\partial x_{b}\left(t_{1} \ldots t_{M}\right)}{\partial t_{k}}$ will be large, while $\frac{\partial x_{b}\left(t_{1} \ldots t_{M}\right)}{\partial t_{j}}$ will be smaller for $\mathrm{j} \neq \mathrm{k}$.

In the event, the above-mentioned target-and-instrument combination may be assigned to a separate institution, in the present case, a specific tier of fiscal authority. The Norwegian economist Leif Johansen has expressed the essence of the matter in the following concise statement (1971: 16):

As a rough principle we could say, then, that instruments affecting many targets ought to be employed centrally, while instruments affecting only one or a small number of targets can to a larger extent be decentralised.

It therefore follows that the inferences to be drawn from the theory of Public Finance are more in the nature of guiding principles than fixed conclusions. This in fact amounts to a particularly useful blend of theory and practice, not always found in economic analysis. To use Adam Smith's famous expression, 
economic enquiry has produced certain canons of taxation (e.g. certainty, clarity, convenience) that separate good and bad fiscal policies.

\section{FISCAL DECENTRALISATION}

Fiscal decentralisation (or devolution) and the related issue of tax assignment (or sharing) are likely subjects of discussion wherever a system of multi-level government and public finance is found. As already mentioned, this paper is concerned with the financial relationship between the national and provincial authorities in South Africa. Matters of local finance are practically excluded, mentioned only in passing.

Fiscal decentralisation is also widely known as fiscal federalism. In a theoretical context, this subject is a branch of Public Finance, including elements of the theories of Public Choice, Taxation, Regional Economics - and more. It is the meeting ground of economics and politics, to be related to states with a federal constitution in the literal sense, for example, the United States, Germany and Australia. However, the term fiscal federalism is used in a less formal and comprehensive meaning too, and may then be applied to any state with more than one level of political authority, which are legion, including South Africa. Here the national government is, in terms of expenditure, chiefly responsible for economic services (finance, trade and industry, labour), protection services (defence, police, prisons, justice), housing and general administration. The main functions of the provinces are primary and secondary education, health and welfare services, provincial roads, regional development, and again housing.

Based on existing intergovernmental arrangements, the national government raises almost all fiscal revenue in the country, but exercises control over only approximately 40 per cent of total non-interest budgetary expenditure. In contrast, the nine provincial authorities control about 60 per cent of total noninterest expenditure, and raise less than 5 per cent (3.6 per cent in 1998/99) towards defraying their aggregate budgetary spending. Central government funds the huge shortfalls that all the provinces have, by means of unconditional grants (or transfers). The roots of this dispensation reach down to the foundation of the Union of South Africa in 1910. Ever since then, the fiscal relationship between the national and provincial governments has been a perennial cause of friction, and in the process the provinces grew increasingly dependent on the fiscal grants of the central government. However, it is determined in the South African Constitution of 1996 that this long-standing trend must henceforth change. This means that the principle of fiscal decentralisaion and the associated redistribution (assignment or devolution) of 
tax revenue from the national to the provincial authorities have become official policy in South Africa. This summary article has been induced by the impending application of the new policy.

However, a fundamental question that calls for detailed discussion and unambiguous clarification is to what extent "decentralization will mean ... the substitution of two or more autonomous policy-makers for a single one, and not merely the execution by a larger number of agencies of a centrally-designed policy" (Tinbergen, 1967: 172).

\section{FISCAL AND FINANCIAL COMMISSION}

The leading role in drawing up the agenda for fiscal decentralisation in South Africa has been taken by the Fiscal and Financial Commission (FFC). The FFC is an independent body established by the Constitution to make recommendations to Parliament and provincial legislatures about financial issues affecting all three tiers of government in South Africa. The position taken by the FFC is summarised below. (The numbers in parentheses in this section refer to page numbers of Appendix $D$ in $M$ Grote's internal report to the Department of Finance.)

\subsection{Surcharge on personal income tax}

The FFC considers a surcharge on the base of national personal income tax (PIT) to be "The only viable source for provincial revenue" (227). It asserts that "The fact that own source revenues make up only a small proportion of total provincial revenue is not in itself sufficient reason to advocate increased revenue-raising powers for provinces", adding the following (228):

A much more compelling reason is that relating to the promotion of democratic and accountable government in the provinces. With provinces currently accounting for less than 5 per cent of their revenues there is little or no incentive for provincial governments to be fiscally accountable to their electorates... Provinces thus spend a large proportion of tax revenue but are not accountable to their electorates for it.

One possible implication of such a situation is that provinces which are largely dependent on transfers from the national revenue pool can be fiscally irresponsible. This was certainly the case during the apartheid era particularly in the so-called self-goveming territories, which were not required to account democratically to their electorates for it. 
The FFC interprets section 228 of the Constitution (see the Introduction above) to mean that provinces already have the right to impose a flat surcharge on the PIT base: "A province does not require authorisation from national government to do so, but it does require national legislation to regulate this activity" (229).

The FFC recommends that a surcharge up to 7 percentage points of the PIT base be phased in over a period of 6 years, by means of the tax room method set out below.

\subsection{Tax burden and tax room}

National government in South Africa has committed itself to limit the total national tax burden on taxpayers to approximately 25 per cent of the gross domestic product. The precondition for the proposed PIT surcharge is thus the creation of enough tax room to prevent the national tax burden from rising. This requires that the national government reduces its overall tax share and makes the decrease available to the provinces as own revenue. If the central government's aggregate grant to the provinces is reduced by the amount of tax room thus created and the provinces levy new taxes to fill up the tax room, then the total funds available to the provinces would remain unchanged.

The FFC gives the following numerical example to elucidate the abovementioned policy shift, which it supports (230):

(i) Suppose that the national average rate for PIT is $25 \%$. At the present time all of PIT is collected at the national level.

(ii) Assume the provinces impose a surcharge of 5 percentage points on the PIT yield (or $5 \%$ on the PIT base).

(iii) If no tax room were created and all provinces imposed the surcharge, the national tax burden for PIT would rise by an average of 5 percentage points.

(iv) However, if the national government agreed to the creation of tax room equivalent to 5 percentage points, the overall tax burden for PIT would remain the same.

(v) Twenty percentage points would then accrue at the national level and five to the provinces.

Although the total revenue received by the provinces from the introduction of the surcharge and an equivalent cut in the central government grant would remain constant, each province would receive additional own revenue after the event. 


\subsection{Tax administration}

The cost of tax administration is an extremely important consideration in an overall tax reform process. A core characteristic of tax-sharing arrangements between national and sub-national levels of government, is generally that a single revenue collection agency is responsible for the tax administration.

The FFC accepts this position and draws the following optimistic conclusion (234):

The FFC is confident, that the tax collection capacity exists in South Africa for the successful implementation of the surcharge. It is envisaged that the South African Revenue Service (SARS) will collect the provincial surcharge on behalf of the provinces, as provided for in the SARS Bill. The creation of provincial revenue services should be avoided.

(We return to this point under 5.3 and 6.2 below.)

\section{THE KATZ COMMISSION}

In July 1998, the seventh interim report of the Commission of Inquiry into Certain Aspects of the Tax Structure of South Africa (Katz Commission) was published under the title Synthesis of Policy Recommendations with regard to Provincial Taxation. As mentioned in our Introduction, the Commission expressed misgivings about the PIT surcharge proposed by the FFC, and made an alternative recommendation how tax devolution might be initiated. The key passages of the report in the present context are briefly quoted below.

\subsection{Constitutional flaw}

The Katz Committee took the view (1998: 5) that the proposed surcharge

... contravenes the provisions of section 228(1) of the Constitution in that it effectively constitutes a flat rate surcharge on national tax rates as opposed to the constitutional requirement of the tax base (i.e. taxable income).

The FFC subsequently conceded this point. 


\subsection{Tax room}

The Katz Commission pointed out (1998: 5) the following ambiguity of the tax room method of fiscal devolution put forward by the FFC:

It needs to be remembered that all nationally collected revenue, including PIT, is shared between the national and provincial governments. Moreover ... the creation of tax room of say 5 percentage points at the national level, will not lead to a fall in revenues accruing to the national level unless provinces do not fully occupy the tax room, in which event there will be a fall in revenues. If, however, provinces raise surcharges higher than the reduction in the national rate, then there will in fact be an increase in revenue. The recommendations of the FFC would permit the occurrence of either of these possibilities.

The redistribution of tax revenue between the national and provincial levels of government depends, at least partly, on whether or not a province is able to recoup the grant revenue it loses from the tax surcharge revenue it gains.

\subsection{Tax administration}

While a surcharge on the PIT base is often found in industrially advanced countries, it has not yet been adopted in a developing economy. This is apparently due to the inadequate tax administration systems in the lastmentioned countries. In the Katz Commission's view, this problem at least partly exists in South Africa too at present (1998: 4):

Without detracting from the important efforts SARS is currently undertaking in its restructuring with a view, inter alia, to the inhancement of its capacity, it is correct to state that at present SARS is still experiencing problems with regard to its capacity. Accordingly, for the same reason that other developing countries have not burdened their tax administrations by the imposition of a surcharge on the PIT base, the Commission has serious concems about doing so in South Africa. To do so in the short term could give rise to risk. This concern is supported by the evidence received from SARS as presented to the Commission.

(See also Appendix C to Grote's internal report: 224-5.) 


\subsection{Surcharge on fuel levy}

The Katz Commission's recommended alternative to the PIT surcharge is a provincial surcharge on the national fuel levy. This option would allow the provincial authorities more freedom of choice with regard to their revenues than at present, and thus be a workable first move in the direction of greater fiscal autonomy at the sub-national level.

The Commission calculated that the tax revenue from the fuel levy surcharge would represent 15.9 per cent of the provinces' total revenue from grants, and further estimated that the total revenue from the proposed fuel levy would be approximately the same as a 5 per cent PIT surcharge, and the Commission comments: "Hence, over the short term concerns about possible revenue yield inadequacies should not disqualify the fuel levy for assignment purposes" (1998: 7). From the perspective of administrative capacity, "the Commission is comfortable that the fuel levy can probably be implemented with a minimum of enforcement and compliance costs on the part of SARS" (1998: 7).

In conclusion, the Katz Commission's report gives a list of the legislative issues to be addressed, if the fuel levy option were to be accepted.

\section{OTHER TAXES}

It should be stressed that every one of the tax instruments outlined below would have to be thoroughly researched before drawing any definite conclusions. However, based on experience of tax policy and international practice, the following points might be noted:

\subsection{Excise taxes on commodities}

In view of the pursuit of a single or common market and to minimise revenue collection costs and policing efforts, the imposition of a provincial surcharge on national excise taxes, or their wholesale transfer to the provinces, should be carefully investigated.

\subsection{Mineral severance and/or production taxes}

Although the findings of the sub-committee tasked to investigate mining taxation should not be pre-empted, it is pertinent to note that there is principally a strong case to be made out for assigning severance taxes based on the benefit principle (or the polluter pays principle) to provincial governments. 


\subsection{Excises on services}

The concept of excise taxes on services can be developed further with regard to the so-called bed-taxes in the tourism industry, airport departure taxes, etc. The respective tax bases are relatively immobile, highly visible and most attractive because these levies are being paid by non-residents of the tax-imposing jurisdiction. Tax exporting is therefore the most likely outcome and, hence, these tax instruments should become the subject matter of thorough national control as they could have wider ramifications, particularly in respect of the national government's tourism promotion policies.

\subsection{Financial services}

Due to administrative problems foreseen with the devolution of charges or imposts on the financial service sector, this source of taxation should not be considered.

\subsection{Marketable securities tax (MST)}

In view of the intemational tendency to abolish MST and the increased competition on intemational capital markets, consideration should be given to the phasing out of this kind of tax. Therefore, its devolution should not be an option.

\subsection{Betterment taxes, valorisation taxes and/or special assessments}

Despite the shortcomings of the betterment tax instrument, it should not be rejected $a b$ initio but be reviewed with regard to its potential of enabling cooperative and participatory government at lower levels. Massive backlogs exist in rural areas where second-tier govemments are responsible for infrastructure such as housing, roads, water supply, etc. Hence, the possible imposition of the betterment tax should be seriously considered and further investigated.

\subsection{Presumptive taxes}

Experience with presumptive taxation suggests that it effectively reduces audit time and cost. But in this connection, it is important to sound the caveat that tax enforcement without adequate safeguards is a threat to taxpayers' basic rights. Thus the use of discretion by tax officials must be minimised and the protection of taxpayer rights must be accorded the highest priority, should the national government find the presumptive tax concept attractive. Against this background, only the central government could guarantee the most conscientious compliance with the preconditions for the presumptive tax 
instrument. Thus, the maximum tax level of presumptive tax instruments per business category (e.g. manufacturing vs service industry) has to be regulated by national framework legislation, after SARS has laid down certain average income norms per business category.

\subsection{Business licence fees}

The introduction of an annual business licence fee as a minimum tax at provincial and local level may be seriously considered. By defining it as a minimum tax, deductible against the nationally collected corporate income tax, tax room would automatically be created and the administration will not need any highly skilled staff, as firms would have to clearly display their business licence token at the entrance to their premises. As the appearance of the licence could be changed from year to year, the policing effort and cost of administration may be minimised, and the compliance gap of corporate income tax could be significantly narrowed with this additional measure.

\subsection{User charges and fees}

Maximising the utilisation of user charges, licence fees or benefit taxes at subnational level, could fund a large portion of the costs of sub-national spheres of government. Furthermore, they give rise to enhanced transparency in the funding of public service provision and, hence, promote a greater degree of accountability. Also, they reduce the risk of tax exporting and usually do not create problems of vertical and horizontal inequity. Thus, the employment of user charges and benefit taxes ought to be maximised as the first step in the incremental process towards efficient effective fiscal decentralisation.

\subsection{Environmental taxes}

Environmental taxes designed to achieve pro-environment and pro-employment outcomes imply an exclusive national responsibility, as this will have farreaching macroeconomic stabilisation impact. Seeing that this approach is internationally used, the possibility of its implementation in South Africa should be investigated.

Other energy taxes, taxes on liquid fuels and road congestion levies could be the responsibility of all spheres of government. However, effluent charges and charges on air pollution (e.g. on pollutants released by coal-fired power stations) that seek to address interprovincial pollution, should also be an exclusive national responsibility. Thus, on the basis of technical advice by the Department of Environmental Affairs as to the most appropriate level of the 
charges to internalise negative externalities, energy taxes and effluent charges should be introduced and administered only by the national government.

Charges or levies on inter-municipal pollution and environmental degradation caused, for example, by natural resource use or extraction activities, could become a provincial responsibility. If the charges were raised on the polluter pays principle, then they would be a true user charge which should be assigned to the respective provincial governments. National framework legislation should, however, provide for a monitoring and approval procedure by the national Departments of Finance and Environmental Affairs concerning the appropriate level of the user charge, in order to prevent it from becoming subnational tax instruments in disguise.

Likewise, intra-municipal pollution (e.g. noise) should remain solely a local govermment responsibility. It is therefore suggested that penalties on explicitly local air pollution transgressions, noise pollution, charges on solid and poisonous waste removal, parking fees to influence inter-modal transport reforms, traffic congestion charges, etc., should remain the prerogative of local governments

\section{ECONOMIC ANALYSIS}

The analysis in this section is predicated throughout on economic efficiency in South Africa and the welfare of its population. The conclusions that follow are of a qualitative rather than quantitative nature. In other words, we seek to discover the probable directions, not estimate the expected magnitude, of the fiscal policy changes adumbrated above. Comprehensive statistical analysis of the issues discussed here will no doubt prove necessary sooner or later, but it seems only sensible to trace out their logical consequences first.

\subsection{Comparative advantage in tax assignment}

The modest attempt in section 2 above to relate various targets and instruments in Public Finance, on the one hand, to different levels of fiscal authority, on the other, produced the following rough guideline: Instruments that affect several targets should be employed at the higher, and those that affect only a few targets, at the lower level of authority. In other words, the former should be centralised and the latter decentralised.

Essentially the same argument may also be stated somewhat differently. For example, available fiscal instruments form a vertical continuum whose opposite ends are the benefit of service principle at the bottom, and the ability to pay 
principle at the top. More particularly, user charges for specific (i.e. excludable) services identify the lowest and general taxes to defray the cost of pure public services (i.e. externalities) the uppermost points of the continuum. It is not far-fetched to view the virtually ubiquitous municipal property rate (tax) as a user charge. Nor should it be controversial to assert that the cost of national security - or law and order - should be met by means of progressive income tax. (After all, the rich have more to lose than the poor!) As always, the ranking of intermediate variables is far from clear-cut, and there is no really "scientific" (or obvious) way of assigning most kinds of tax to either the national or the provincial authorities. Rather, tax assignment depends more on practical circumstances than theoretical principles.

However, though it would be simplistic to demand that "a given fiscal authority should employ only those taxes it can best manage and no others" (Netzer, 1974: 186), something akin to the principle of comparative advantage in international trade seems to be working in the field of fiscal assignment too.

Thus, in the present case, central government in South Africa no doubt manages both income tax and the fuel levy more efficiently than the provincial governments would do. But it also seems most probable that the central government's advantage is comparatively greater in the case of income tax. By the same token, the provincial governments' disadvantage is comparatively smaller in the case of the fuel levy. Therefore, a surcharge on the fuel levy rather than the personal income tax base seems the more efficient instrument of fiscal devolution in South Africa.

\subsection{Tax administration}

There is general agreement in official and knowledgeable circles, that the cause of tax devolution would be best served if tax administration remains centralised in the South African Revenue Service (SARS). Only SARS has prospective economies of scale or, conversely, reasonably low cost of administering the country's tax system. Views differ, however, on whether SARS has the capacity at present to accommodate the PIT surcharge proposed by the FFC. The latter itself sees no serious problem on this count (section 4.3 above). The Katz Commission, however, disagrees (section 5.3), at the same time saying that SARS would in fact be able to manage its own fuel surcharge proposal economically (section 5.4 ).

Surely it should be possible to settle the validity of these opposing claims by factual examination. In its 1999 Budget Review, the Department of Finance outlined various administrative improvements taking place at SARS, including such productive inputs as enhanced audit capacity and new computer-based 
audit systems. In its submission to the Katz Commission, dated 3 September 1997, SARS itself pointed out several administrative problems and made the following conclusion (Ap C: 225):

Should it be decided that ... a surcharge be levied on personal income tax, SARS will not be in a position to introduce such a system before the tax year commencing on I March 1999.

More recent information would seem necessary to reach a meaningful verdict on the economic relationship between tax devolution and tax administration in South Africa.

\subsection{Non-economic arguments}

Both parties to the PIT-fuel levy surcharge controversy use arguments either not based on economic reasoning at all, or not sufficiently supported by the economic facts of life. This makes objective assessment of some of their policy proposals difficult, to say the least. The FFC's assertion that greater provincial tax powers would promote "democratic and fiscally accountable government" is an assumption that cannot be proved either right or wrong at present (section 1 above). It is a noble sentiment uttered in all good faith - but no more. On the other hand, it is difficult to understand the Katz Commission's refusal to consider the assignment of excise taxes on commodities to the provinces (1998: 9). The ostensible reasons for it - "[not] intemational best practice" and "the limited geographical size of South Africa's nine provinces" - are unconvincing from an economic point of view. At least the second "reason" could be used to argue against the Commission's own recommended provincial surcharge on the fuel levy too - even with greater force than in the case of the excise taxes on, say, tobacco and alcohol. All three products have a price-inelastic demand, which makes them outstanding candidates for any kind of fiscal impost. The matter evidently merits further study.

However, a more serious problem is a general lack of objective information about several matters relevant to the tax devolution issue as a whole, aside from the question of tax administration briefly discussed in the previous sub-section.

\subsection{Research agenda}

In this sub-section we no more than highlight some topics that appear to call for further research. Thus, finding answers to questions like the following should help to clarify the complex process of fiscal decentralisation on which South Africa has embarked. 
- Is there a net (negative) effect on income when a given provincial grant is replaced by an equal amount of own revenue, similar to the balanced budget multiplier?

- How many social versus private benefits would be affected by the abovementioned operation?

- What are the possible effects of fiscal devolution on the supply of pure public goods?

- How much "tax migration" (i.e. tax avoidance) and other spillover effects is interprovincial tax competition likely to cause?

- What are the expected interprovincial consequences of horizontal and vertical redistribution of resources, when the former do and the latter do not contain an "equitable share" component?

- What would be the economic effects of transferring commodity excise taxes (e.g. on tobacco and alcohol) from the national to the provincial authorities?

- If provincial expenditure targets are given, how much freedom of choice is new provincial own revenue likely to represent?

- A particularly important research undertaking would be to investigate how fiscal decentralisation would affect the issues highlighted in section 288(2) of the Constitution, namely, economic policies, activities across provincial borders, and the national mobility of goods, services, capital and labour.

As the process of fiscal devolution grows, new topics are bound to be added to the research agenda.

\section{CONCLUSION}

The specific question around which much of this paper (especially sections 4 and 5) is structured, whether a surcharge on the personal income tax base or the fuel levy should be the first step in the direction of fiscal decentralisation in South Africa, has already been answered in section 7.1. On the principle of comparative advantage in tax assignment, we found in favour of the fuel levy surcharge.

Our most important general conclusion is that the tax devolution process, in its early stages is, likely to be a learning process that should not be artificially hurried. At least some provinces initially experienced problems of 
overspending, but these have by now improved under the guidance of the national government (BR: 92). At present again, some provinces have difficulty in spending their total budget allocations on account of capacity limitations. A similar process of tutelage is likely to be required for fiscal decentralisation too. It is to be hoped that this process of "learning by doing" would be accompanied by ongoing research into issues of fiscal devolution in South African conditions.

In this context, it would be most useful if the ends-means relations that characterise fiscal decentralisation could be successfully conveyed to the participants in this endeavour. Above all, provincial governments should grasp the fact that increased own revenue is not an economic end in itself, but the means of both regional and national efficiency and welfare.

\section{REFERENCES}

1 GROTE, M. (1999) Internal Report to the Department of Finance.

2 JOHANSEN, L. (1971) Public Economics, Amsterdam: North-Holland.

3 KATZ COMMISSION (KC) (1998), Seventh Interim Report: Synthesis of Policy Recommendations with regard to Provincial Taxation.

4 NETZER, D. (1974) "State-Local Finance and Intergovernmental Fiscal Relations", The Economics of Public Finance, Washington, DC: The Brookings Institution.

5 REPUBLIC OF SOUTH AFRICA (1999) Department of Finance Budget Review (BR) 1999.

6 TINBERGEN, J. (1967) Economic Policy: Principles and Design, Amsterdam: North-Holland. 